\title{
Urban Flooding, Adaptation Strategies, and Resilience: Case Study of Accra, Ghana
}

\author{
Kwadwo Owusu and Peter Bilson Obour
}

\section{Contents}

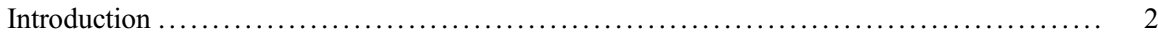

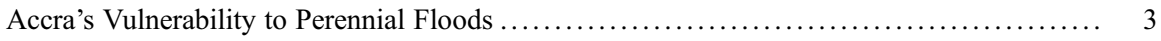

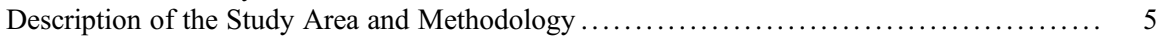

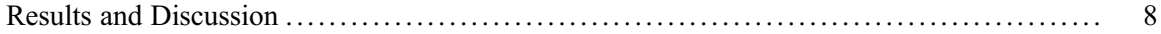

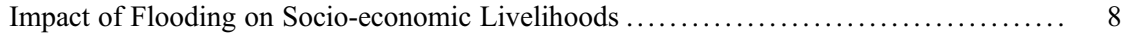

Flood Control and Adaptation Measures ..................................... 9

Summary Types of Adaptation Measures to Flooding in Accra ..................... 11

Limits and Barriers to Adaptation to Flooding .................................. 13

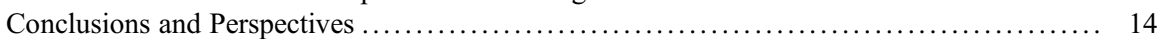

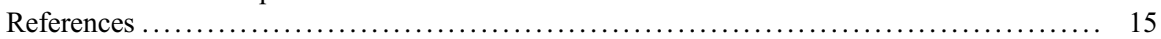

\section{Abstract}

Despite massive flood controlling investments, perennial flooding continues to be a major challenge in the Greater Accra Metropolitan Assembly in Ghana. Previous studies have mostly considered the vulnerability of Accra to flooding induced by urbanization and climate change. This chapter examined the impacts of and adaptation strategies to flooding in two flood-prone residential areas in Accra. A survey was conducted among 320 household heads to ascertain local impacts of floods and community adaptation strategies. To obtain a broader picture of government interventions and challenges, key stakeholders such as personnel from ministries, departments, and agencies who are involved in city planning, and

This chapter was previously published non-open access with exclusive rights reserved by the Publisher. It has been changed retrospectively to open access under a CC BY 4.0 license and the copyright holder is "The Author(s)". For further details, please see the license information at the end of the chapter.

K. Owusu · P. B. Obour $(\bowtie)$

Department of Geography and Resource Development, University of Ghana, Legon, Ghana e-mail: kowusu@ug.edu.gh; pbobour@ug.edu.gh 
private urban planning consultants were interviewed. The study found that a notable driver of floods in Accra is blocked waterways, and flawed and ad hoc engineering works. About three-quarters of the households interviewed have suffered flood-related losses over the past decade such as housing damage, income, and even a death of a relative. Key flood control interventions included dredging prior to start of rains and sporadic demolition of unauthorized buildings on or near waterways to allow free flow of water. However, these interventions only seem to be ephemeral due to the rapid rate of littering and re-siltation of the waterways after few rain events. The study highlights the need for more pragmatic and robust engineering solutions to build resilience of Accra to floods.

\section{Keywords}

Barriers to adaptation - Flood control interventions $\cdot$ Perennial flooding $\cdot$ Socioeconomic livelihoods

\section{Introduction}

Urban flooding is one of the major hydro-climatic disasters which is increasing in frequency and intensity and affecting regions worldwide. Flooding causes serious economic, social, health, cultural, and environmental impacts that affect sustainable development (Kim et al. 2017), particularly in developing regions because of high poverty levels, and poor urban planning and building architecture. Different types of floods can be identified based on the source of water and the process giving rise to the flooding event (Viglione and Rogger 2015). This study focuses on urban floods occurring independently and/or in conjunction with flash and river floods. As at the year 2000, global urban land susceptible to floods was estimated to be around $195,493 \mathrm{~km}^{2}$ (Güneralp et al. 2015). Africa is one of the continents highly affected by flood-induced disasters, particularly in urban areas. The vulnerability of African cities to urban flooding is partly due to the fast rate of uncontrolled urbanization and its associated problems which constrained flow of water (Amoako 2012; Aboagye 2012; Dewan 2015).

In Ghana, flooding is among the top 10 natural disasters and hazards and ranks second after epidemics such as bacterial and viral infectious diseases, affecting over three million people and causing huge economic losses each year (Okyere et al. 2012). The country has experienced increasing flood events over the years - the severest floods in the last two decades occurred in the years 2007, 2010, 2011, 2015, and 2020, which hit many parts of the country, particularly major urban areas. For instance, on June 22, 2010, 35 bodies were retrieved from flood waters across the country by volunteers and rescue workers (Daily Graphic 5 June, 2015), and on June 3 , 2015, flooding with an associated fire killed about 200 people in the commercial hub of Accra (BBC 2015). The consequences of flood-induced disasters in urban areas include loss of properties and lives as outlined above, which also have shortand long-term adverse consequences on urban poverty and development. 
Global climate change impacts are likely to increase hydro-climatic disasters like flooding in urban areas. The recent Intergovernmental Panel on Climate Change (IPCC) Special Report on the impacts of global warming of $1.5^{\circ} \mathrm{C}$ above preindustrial levels and related global greenhouse gas emission pathways projects increase in the frequency and magnitude of flood due to changing precipitation patterns (IPCC 2018). Despite the large uncertainties in the magnitudes of climate change impacts on waterrelated shocks, increased frequency of extreme rainfall events will pose a serious threat to urban resilience and sustainability in many developing countries. The high vulnerability of these regions to extreme climatic events results from their low resilience and weak adaptive capacity (IPCC 2007). Adaptation to flood-related impact is not an option but a necessity, which must be embraced across all spheres of planning. However, while the vulnerability of urban areas to flood-related disasters is largely studied, the local impacts and, more importantly, multilevel flood adaptation strategies are poorly understood especially in developing countries.

To contribute to a better understanding of climate change impact on urban areas in Ghana to disasters, and identify key adaptation challenges to guide decision making and for prioritizing city planning needs, a study was conducted in two flood-prone coastal metropolitan areas of Accra and Sekondi-Takoradi. Part of the results recently published by Owusu et al. (2019) investigated the physical and social vulnerability of the two urban cities to climate-induced disasters. Key findings highlight the need to prioritize perennial flooding to safeguard lives and property and to strengthen the cities' resilience to flood-related disasters. Following up on the previous findings by Owusu et al. (2019), the present chapter investigates incidence of flooding, adaptation strategies, and resilience in Accra. Specifically, the study (i) examined impact of floods on socio-economic livelihoods and (ii) explores multilevel flood control measures and adaptation strategies, and associated shortfalls, that is, why interventions to tackle flooding in Accra have been ineffective? It is hoped that a better understanding of flood control measures and adaptation practices and pitfalls would provide essential information on successful adaptation options and help to identify the interventions that need to be improved to build the resilience of Accra and other cities in Ghana to flood-related disasters.

\section{Accra's Vulnerability to Perennial Floods}

The term vulnerability has been used by different authors to connote different meanings. Beyond the multidimensional usage of the term vulnerability, most comprehensive and accepted definition in the context of climate change has been given by the IPCC (2000) as: "the degree to which a system is susceptible to, or unable to cope with adverse effects of climate change, including climate variability and extremes." Thus, vulnerability of any system has generally been accepted as a function of three elements: exposure to a hazard, sensitivity to that hazard, and the capacity of the system to cope with and adapt or recover from the effects of those conditions (Jamshidi et al. 2019). Here, vulnerability is used to encompass both the exposure and susceptibility of population to floods. Thus, the chapter examines the 
Table 1 Magnitude of daily precipitation and flood events and the number of affected people in Accra (1959-2020)

\begin{tabular}{|c|c|c|c|c|c|c|}
\hline Date & $\begin{array}{l}\text { Precipitation- } \\
\text { a day before } \\
\text { floods }(\mathrm{mm})\end{array}$ & $\begin{array}{l}\text { Precipitation- } \\
\text { flood day } \\
(\mathrm{mm})\end{array}$ & $\begin{array}{l}\text { Monthly } \\
\text { total } \\
(\mathrm{mm})\end{array}$ & $\begin{array}{l}\% \text { of } \\
\text { precipitation } \\
\text { on flood day }^{\mathrm{a}}\end{array}$ & $\begin{array}{l}\text { Number } \\
\text { of people } \\
\text { affected }^{b}\end{array}$ & Reference \\
\hline June $1959^{c}$ & - & 192 & - & & - & \\
\hline $\begin{array}{l}\text { June 27, } \\
1960\end{array}$ & 0 & 98 & 371 & 26 & - & $\begin{array}{l}\text { (Daily Graphic } \\
\text { 2015) }\end{array}$ \\
\hline $\begin{array}{l}\text { September } \\
29,1963\end{array}$ & 0 & 97 & 190 & 51 & - & \\
\hline $\begin{array}{l}\text { July 4, } \\
1968^{\text {d }}\end{array}$ & 5 & 33 & 372 & 9 & $>1000$ & $\begin{array}{l}\text { (Asumadu- } \\
\text { Sarkodie et al. } \\
2015 \text { ) }\end{array}$ \\
\hline $\begin{array}{l}\text { June 22, } \\
1973\end{array}$ & 0.3 & 175 & 411 & 43 & - & \\
\hline $\begin{array}{l}\text { July 14, } \\
1991\end{array}$ & 2 & 157 & 263 & 60 & - & \\
\hline $\begin{array}{l}\text { July 3, } \\
1995\end{array}$ & 0 & 244 & 274 & 89 & $>1000$ & $\begin{array}{l}\text { (Kwarteng } \\
\text { 2007) }\end{array}$ \\
\hline $\begin{array}{l}\text { June 13, } \\
1997\end{array}$ & 38 & 114 & 353 & 32 & $1000 \mathrm{~s}$ & $\begin{array}{l}\text { (Asumadu- } \\
\text { Sarkodie et al. } \\
\text { 2015) }\end{array}$ \\
\hline $\begin{array}{l}\text { June } 27, \\
2001\end{array}$ & 27 & 81 & 247 & 33 & 100,000 & $\begin{array}{l}\text { (Aboagye } \\
\text { 2012; CNN } \\
\text { World 2001) }\end{array}$ \\
\hline $\begin{array}{l}\text { June 9, } \\
2002\end{array}$ & 0 & 123 & 421 & 29 & $\sim 1500$ & $\begin{array}{l}\text { (United } \\
\text { Nations Office } \\
\text { for the } \\
\text { Coordination } \\
\text { of } \\
\text { Humanitarian } \\
\text { Affairs } \\
\text { (OCHA) 2002) }\end{array}$ \\
\hline $\begin{array}{l}\text { March 26, } \\
2007\end{array}$ & 0 & 59 & 63 & 95 & - & \\
\hline $\begin{array}{l}\text { May 18, } \\
2008\end{array}$ & 0 & 151 & 395 & 38 & - & \\
\hline $\begin{array}{l}\text { October } \\
25,2011\end{array}$ & 58 & 98 & 184 & 53 & 43,000 & $\begin{array}{l}\text { (The Weekend } \\
\text { Globe 2013) }\end{array}$ \\
\hline $\begin{array}{l}\text { June 3, } \\
2015^{\mathrm{e}}\end{array}$ & - & - & - & - & $>10,000$ & $\begin{array}{l}\text { (Daily Graphic } \\
5 \text { June, 2015) }\end{array}$ \\
\hline $\begin{array}{l}\text { June } 8, \\
2020\end{array}$ & - & - & - & - & $>50,000$ & (Darko 2020) \\
\hline
\end{tabular}

Source of precipitation data: Ghana Meteorological Agency (GMet), Accra.

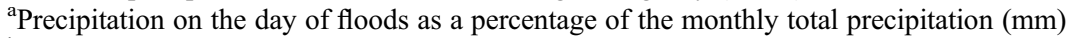

${ }^{\mathrm{b}}$ People requiring immediate assistance during an emergency situation plus those injured and homeless

${ }^{\mathrm{c}}$ Reported amount of rainfall from Daily Graphic (5 June, 2015)

${ }^{\mathrm{d}}$ Precipitation of $148.3 \mathrm{~mm}$ was recorded 2 days before day of flood

${ }^{\mathrm{e}}$ Flood ignited fire flames in a fuel station. Number of lives lost included victims killed by the fire 
exposure of residents in Accra to flooding and the ensuing burden on socio-economic livelihoods and sustainable development in the city.

Accra is a primate city in Ghana with a long history of flood-related disasters as illustrated in Table 1. Records of major flood incidence in the city date back to June 1959 (Daily Graphic 5 June, 2015). More than 16 deadly flood disasters have been recorded since 1959, all of which have caused severe damages to life and property. The vulnerability of Accra to flooding has been attributed to natural factors and processes like its low-lying topography, increase rate of coastal erosion, frequency of torrential rainfall in recent years, combined with anthropogenic factors such as rapid urbanization, chocked drains, and blocked watercourses (Jamshidi et al. 2019; Asumadu-Sarkodie et al. 2015; Appeaning Addo and Appeaning Addo 2016). For instance, on July 3, 1995, the Ghana Meteorological Agency (GMet) recorded $243 \mathrm{~mm}$ of rain with a peak intensity of $64 \mathrm{~mm}$ in $12 \mathrm{~min}$. The rain lasted for approximately $5 \mathrm{~h}$ resulting in flooding in Accra and its environs (Kwarteng 2007) and on May 18, 2008, and October 25, 2011, 156 mm of rain water was recorded in less than $10 \mathrm{~h}$ resulted in a deadly flood in many parts of Accra (The Weekend Globe 2013). According to Maskey and Trambauer (2015), the main process leading to flooding is precipitation falling over an extended period of time in an area which produces runoff due to saturation (antecedent soil moisture) and excess infiltration. The relationship between heavy downpours and incidence of flooding (due to rapid peak flows) has been explained using run-off models (e.g., Asumadu-Sarkodie et al. 2015). Jahanbazi and Egger (2014) stress that extreme rainfall leads to flooding when urban drainage system fails to drain the total amount of rainwater, resulting in what could be termed as an urban pluvial.

Considering that changes in precipitation patterns and extreme rainfall associated with climate change will increase the vulnerability of cities to flooding in many regions (Willems et al. 2012), flooding in Accra will continue to be a major socioeconomic and development challenge more than ever. A better understanding of management of flooding and failures is vital to develop sustainable solutions and building the resilience in flood-prone areas in Accra.

\section{Description of the Study Area and Methodology}

Accra is the largest metropolitan area in Ghana and has been the administrative capital city of the country since 1877. It has a total land area of $201 \mathrm{~km}^{2}$ (UN-Habitat 2009). The city has experienced a rapid growth and it is one of the fastest-growing cities in West Africa with an estimated annual average growth rate (2010-2020) of $2.2 \%$ (www.macrotrends.net 2020). Accra has physically developed very quickly particularly along the arteries of the major road network radiating from the city center to the countryside (Møller-Jensen et al. 2005). Another worrying trend is the increasing physical development along the low-lying coastal and flood-prone areas of Accra threatening the ecology of coastal lagoons and estuaries (Owusu et al. 2019). The population in the city has increased from about 177,000 inhabitants in 1950s to about 2.5 million inhabitants by the close of 2019 (www.macrotrends.net 
2020 ) and accommodates approximately $8.4 \%$ of the $\sim 30$ million people in Ghana. Unfortunately, infrastructure and service provision is behind the physical development of Accra and has placed pressure on housing and worsened the already high housing deficit in the city (Rain et al. 2011). As a result, there are many areas that are unplanned or where inadequate planning has been carried out by the land-owners who attempt to integrate their development into the statutory land use plan of Accra leading to a proliferation of slums with about $38 \%$ of the city's population living in these underserved settlements (UN-Habitat 2011).

The physical location of Accra in the dry coastal foothills of the Akwapim ranges renders the city vulnerable to flooding. Accra is mostly low lying with average elevation around $20 \mathrm{~m}$ and bordered by few hills to the west and northwest. It is drained by many rivers like the Odaw and Dzorwulu that originate from the Akwapim hills. Rainfall in the Southeast of Ghana where Accra is located has high variability (with coefficient of variation of above 30\%) which results in high frequent of rainfall extremes (Owusu and Teye 2015). Two residential classes in Accra, namely, second and third areas prone to perennial flooding (Owusu et al. 2019), were selected for the study. The specific neighborhoods were: second class residential areas (Kaneshie, Abelemkpe, and Asylum Down) and third class residential areas (Adabraka, Alajo, Avenor, Odawna, Mataheko, Nima, and Mamobi). The vulnerability of the neighborhoods to flooding is partly due to the low-lying topography (lies a few meters above sea level) and uncontrolled slums (Owusu et al. 2019). The geographical spread of the study sites (Fig. 1) was to ensure that we obtained a wide and representative data.

Primary data for the study were collected using the procedure described in Owusu et al. (2019). In brief, data on impacts of flooding on household livelihoods, mitigations and adaptation strategies, and barriers were collected at household and institutional levels. A combination of stratified and simple random sample survey were conducted in the neighborhoods located in the two residential classes. A total of 320 household heads were interviewed, which comprised 90 and 230 in the second and third class residential areas, respectively. Data collected included background information, experience, and narration of impact of flooding in the area of residence and individual and/or community preparedness and response.

Interviews were conducted with construction engineers and relevant institutions such as the Departments of Physical Planning, Development Planning, Urban Roads, and National Disaster Management Organization (NADMO), Geological Survey Department, and the Ghana Water Company Limited (GWCL) in Greater Accra Metropolitan Assembly (AMA) to provide further insights into the household surveys and preparedness and flood-mitigation measures rolled out by the metropolis to control perennial flooding in Accra. To supplement the data on flood-mitigation measures in the Accra, secondary data collection was done to obtain information on past and current public (government) invested projects to tackle flooding and its associated impacts on socio-economic livelihoods on the population. The secondary data were sourced from newspapers, journal articles, and government documents. Both the primary and secondary data were manually analyzed to establish themes and patterns based on the objectives of the study. 


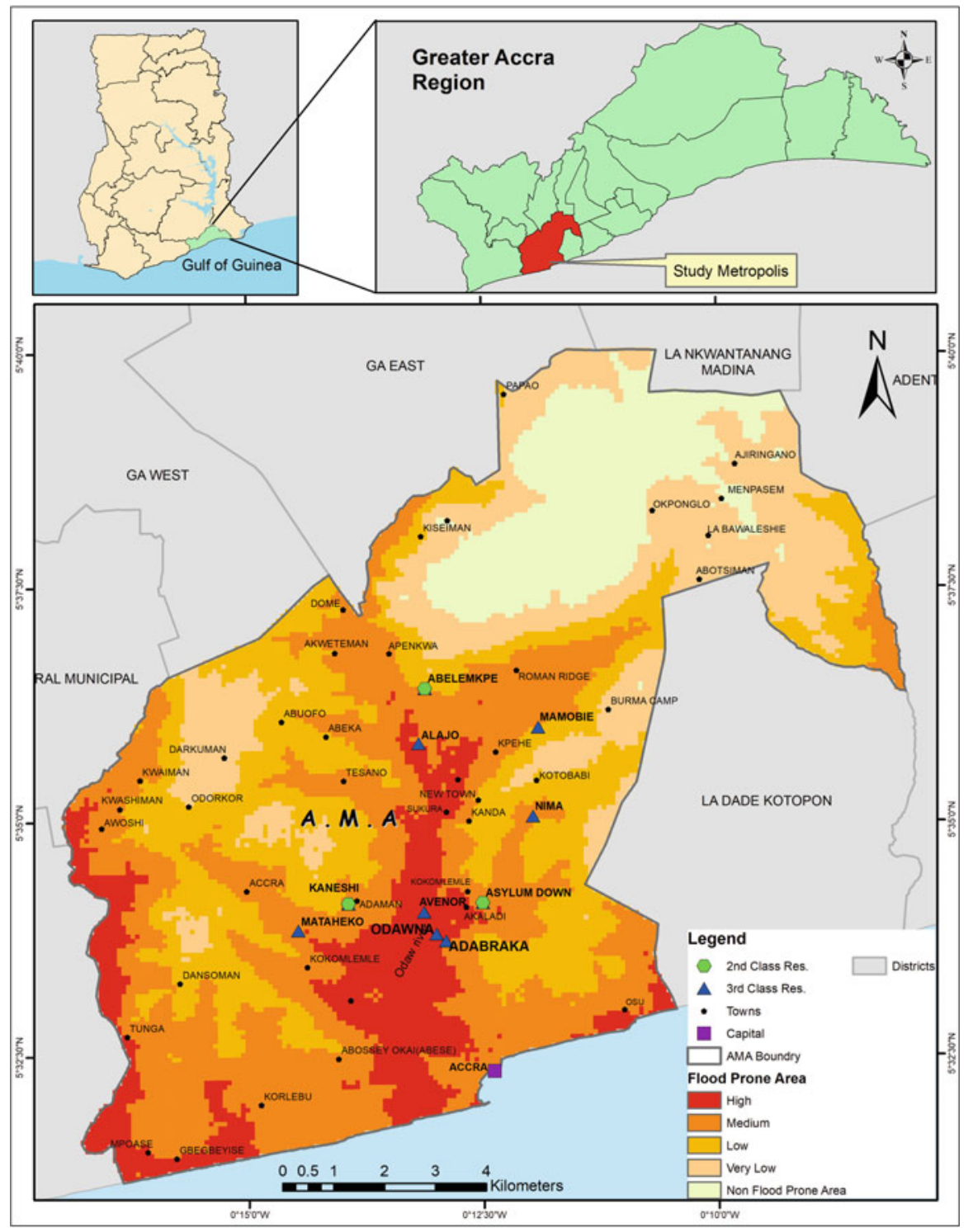

Fig. 1 Map of Accra showing the study locations and flood-prone areas. (Source: Authors) 


\section{Results and Discussion}

\section{Impact of Flooding on Socio-economic Livelihoods}

Both the household and stakeholder interviews indicate that flooding has socioeconomic tolls on households, the metropolitan assembly, and the nation. The impact on household livelihood reported included loss of property such as buildings and other personal belongings, and self-employed businesses. The respondents interviews in both residential areas investigated revealed that property damage during flood varied considerably between households, ranging from hundreds to several thousands of dollars across households in the seven study sites. However, for poor record keeping and reluctance of the respondents in providing information on economic losses, exact monetary damages to household could not be ascertained. Nevertheless, the estimates reported in the present study corroborates the information sourced from stakeholders and what has been reported in earlier studies. Previous studies in Accra estimated property damage due to flooding in the city on July 3, 1995, and on June 13, 1997, ranged from thousands to millions of dollars (Kwarteng 2007; Aboagye 2012). Interviews held with NADMO officials showed that the nation spends a lot of money on flood events in AMA - it constitutes expenses on relief items like blanket, mattresses soap, food, and sometimes temporary structures for flooding affected households.

Results from the present study showed that the magnitude of flood-related damages and losses largely depended on household characteristics such as the economic value of personal belongings of affected-households, and more importantly, whether flood warning were issued prior to a flooding episode. The main source of information on risk of flooding reported by the respondents was flood alert warnings issued by the GMet. Thus, the interviews revealed that reported floodinduced damages were high among respondents who own several and/or valuable properties such as electronic appliances, furnished homes, and those who were engaged in self-employed business in the same neighborhood where they lived or in another flood-prone area in Accra. Further, results from the household interviews demonstrated that economic impact of floods in terms of property damage, in general, tends to be low when households anticipated risk of flooding during a rain storm/event from warnings issued by the GMet. In that case they were able to move some of their belongings to relatives and friends who lived in low flood risks areas in the city.

Further, physical destruction of buildings means household loss their homes. Over $65 \%$ of the respondents in both residential areas reported that they or someone they knew had been homeless for a few weeks to several months after flooding in the last decade. The respondents mentioned that being homeless has both economic and psychological consequences on their households, though the latter could not be readily quantified. According to a respondent: “...Being homeless, especially when you have a family makes you feel like you have life without soul or sailing without direction." 
In addition to property losses, all the respondents emphasized that flooding in Accra posed physical danger on lives and health of households, such as injuries on the day of flooding and an outbreak of cholera and other water-borne diseases after flooding. About 30\% of the households, mainly in Alajo, Avenor, Odawna, and Adabraka, reported that they have lost a relative or someone they knew due to floodrelated disasters in the past decade, probably due to the close proximity of the neighborhoods to the Odaw River which frequently overflows its banks during rainstorms. Cost of treating injuries immediately or a few days following flooddisasters was reported to be free of charge because AMA took care of the medical bills, whereas cases reported several days after flooding were not treated for free. This means "unless a patient is a national health insurance scheme participant, they have to pay for cost of health care services." The present study demonstrates that the overall impacts of flooding on household livelihood in Accra may be higher than previously thought. According to Maskey and Trambauer (2015), hydro-climatic hazards have tangible impacts that are easily quantifiable and intangible that are not easily quantifiable. Owusu and Teye (2015) found that property loss and death associated with urban flooding in Accra could be remarkably high, but evaluation is limited by lack of data. It is interesting and relevant for future studies to map and quantify the actual socio-economic, health, and psychological burden of flooding on households in Accra using proxy data such as cost of treating injuries and/or disease morbidity, lost wages, time spent for caring for sick or injured household member, etc., to provide a robust documentation and clear picture of impact of floods. Such information can be very useful for prioritizing government- and private-led schemes for supporting flood-affected households in Accra.

\section{Flood Control and Adaptation Measures}

Results from the interviews and detailed review of secondary literature demonstrating the detrimental impact of flooding on household livelihood and economic implications for the nation (e.g., Mensah and Ahadzie 2020; Ahmed et al. 2018) suggest that flood control in the short-term or adaptation in the long-terms is imperative. However, it is intriguing to point out that the long flood history of Accra has, indeed, shaped the interaction between local and/or metropolitan activities and development, and flood control and adaptation practices. In the following section, the individual and communities, and metropolitan flood control and adaptation interventions, as well as some pertinent barriers to adaptation, are discussed. To better understand the spatial dimensions of community interventions, that is, whether household flood control and/or adaptation strategies are influenced by their physical local or vulnerability to flooding, flood control, and/or adaptation strategies reported by the respondents are discussed in light of the two residential classes investigated. 


\section{Individual and Community}

Results indicated that individuals in the study areas are coping by adopting a combination of flood control and adaptation practices. For respondents who lived a few meters away from main drains, a key control measure reported was the digging of temporary channels from their homes to the main drain to ensure free flow of water during torrential rain event. However, the practices, in general, were reported to be less effective and less reliable because the main river channel is often choked.

Eighty-five percent of the respondents in marginal areas like flood plains and swampy areas indicated that they have adapted to flooding by taken drastic accommodation steps. The key reported ones included: (i) changing from building expensive permanent concrete block structures to building cheaper temporary structures such as simple wood structures or metal containers. Fifty-eight percent of the respondents who lived in temporary structures held the opinion that living in those structures were necessary to alleviate huge capital losses when the structure is damaged or lost due either to demolition exercises periodically carried out by AMA to bring down unauthorized structures on and near waterways, or the structure is damaged during flooding. (ii) The respondents in both residential classes reported that they also controlled flooding by desilting drainage channels in their neighborhoods. The cost of dredging is sometimes fully supported by AMA through the local assembly. However, they emphasized that such a support was not regular. Therefore, the common practice has been organizing communal labor to dredge some of the sections of the drainage channels themselves. Further, the interviews revealed a few relatively rich individuals in both residential areas sometimes employed the services of private dredging companies to desilt all or a section of drainage channels closed to their homes to allow free flow of water, which helps prevent flooding. (iii) Another individual adaptation practice reported by $52 \%$ and $48 \%$ of the respondents in the third and second class residential areas was temporary vacation of homes located on and near waters during the rainy season, especially when the GMet issued an alert that flooding in Accra was imminent. Findings are consistent with previous observations (e.g., Mensah and Ahadzie 2020) showing that in flood-prone areas, people adopt reactive strategies like relocating and protecting properties, for instance, by practicing early transfer of personal belongings to safe places prior to onset of rains. The present study further showed that flood-forecasting by the GMet plays a crucial role in strengthening household seasonal adaptation practices and thus, helps to alleviate the negative impact of flooding on socio-economic livelihoods.

Households in the highly flood-prone residential areas, particularly in Alajo, Adabraka, Avenor, and Asylum Down, have adapted to the economic shocks of flooding by enrolling in life and property insurance schemes, which according to them provided an economic cushion in times of flood-related disasters. However, because premiums and monthly charges can be prohibitively expensive for, especially, low-income households, only a few of the respondents (18\%) reported that they had life and/or property insurance. 


\section{Metropolitan Assembly/Government}

The household and stakeholder interviews pointed out two key areas of institutional or government 'action plans" to managing flooding in Accra. A common approach, which has for many decades been adopted by AMA, was routine dredging of water channels, notably the Odaw River and Korle-Lagoon. The Odaw River has a wide catchment area and covers most parts of Accra and feeds into the Korle-Lagoon, which empties the content of the Odaw and other drainage channels into the Gulf of Guinea (Owusu Boadi and Kuitunen 2002; Ministry of Works and Housing 2019). Table 2 presents an overview of government flood control and adaptation projects in Accra in the last decade implemented during the rainy season before or after flood disasters. Table 2 illustrates two important considerations: (i) the state has spent substantial amount of money in the past decade on measures to prevent flooding in Accra, and (ii) flood prevention measures have mainly been dredging to unblock major waterways and drainage systems prior to the rainy season. Findings of the study highlight that although the dredging projects required massive capital investment, the persistence of flooding in Accra is a strong evidence that the project may be providing ad hoc solutions with very minimal long-term impacts as previously reported by Owusu et al. (2019). Evidence here suggests a need for government to rather consider massive capital investments such as the construction of more robust drain, which can offer sustainable solutions for controlling flooding in Accra and in other flood-prone cities in Ghana.

Another institutional intervention reported was the demolition of unauthorized buildings on or near waterways to allow free flow of water. Demolition of building is an exercise regularly carried out by AMA prior to the start of the rainy season, especially when torrential rains were expected in Accra and its surroundings. The interviews revealed that likewise dredging, demolition also only offers a short-term solution for managing flooding because the demolished structures are re-erected shortly after the AMA-led demolition exercise is completed.

\section{Summary Types of Adaptation Measures to Flooding in Accra}

Alcamo and Olesen (2012) proposed that climate change adaptation measures could be classified into the following: autonomous vs. planned, anticipatory vs. reactive, centralized vs. decentralized, and gradual vs. abrupt. Although these classifications were originally proposed in relation to climate change, they could be applied in the present study to classify the adaptation measures to flooding. Results showed that adaptation at the individual level encompasses both autonomous and planned adaptation practices. Decisions taken by households on where to relocate to when flood warnings are issued by GMet are mainly taken at the family level. The planned adaptation measures adopted by the individual included the construction of improvised channels from homes to main drains to ensure free flow of water. Dredging of drainage channels by community and/or government prior to the onset of rain is both anticipatory (i.e., in anticipation to control risk of flooding during the rainy season) 
Table 2 Overview of government investments (2010-2020) to control flooding in the Greater Accra Metropolitan Assembly

\begin{tabular}{|c|c|c|c|c|c|}
\hline Project & $\begin{array}{l}\text { Date } \\
\text { (period) }\end{array}$ & Description & Cost (US\$) & Sponsors & Reference \\
\hline \multirow[t]{3}{*}{$\begin{array}{l}\text { Greater Accra } \\
\text { Resilient and } \\
\text { Integrated } \\
\text { Development } \\
\text { Project }\end{array}$} & \multirow[t]{3}{*}{$\begin{array}{l}2019- \\
2025\end{array}$} & $\begin{array}{l}\text { Phase 1: mitigating the } \\
\text { flood risk for a } 10 \% \\
\text { annual exceedance } \\
\text { probability flood in the } \\
\text { Odaw River Basin }\end{array}$ & 200 million & $\begin{array}{l}\text { Dutch } \\
\text { Government } \\
\text { and the } \\
\text { World Bank }\end{array}$ & $\begin{array}{l}\text { The World } \\
\text { Bank } \\
(2019)\end{array}$ \\
\hline & & $\begin{array}{l}\text { Phase 2: expanding } \\
\text { flood mitigation and } \\
\text { drainage } \\
\text { improvements to } \\
\text { additional priority } \\
\text { basins (such as Lafa, } \\
\text { Sakumo, Kpeshie, and } \\
\text { Densu asins) }\end{array}$ & 300 million & $\begin{array}{l}\text { Dutch } \\
\text { Government } \\
\text { and the } \\
\text { World Bank }\end{array}$ & $\begin{array}{l}\text { The World } \\
\text { Bank } \\
(2019)\end{array}$ \\
\hline & & $\begin{array}{l}\text { Phase 3: scaling up the } \\
\text { project to the } \\
\text { remaining priority } \\
\text { basins of the Greater } \\
\text { Accra Region (GAR) } \\
\text { to mitigate flood risk in } \\
\text { the entire GAR }\end{array}$ & 400 million & $\begin{array}{l}\text { Dutch } \\
\text { Government } \\
\text { and the } \\
\text { World Bank }\end{array}$ & $\begin{array}{l}\text { The World } \\
\text { Bank } \\
(2019)\end{array}$ \\
\hline $\begin{array}{l}\text { Korle Lagoon } \\
\text { Ecological } \\
\text { Restoration } \\
\text { Project }\end{array}$ & $\begin{array}{l}2015- \\
2016\end{array}$ & $\begin{array}{l}\text { Dredged the Odaw } \\
\text { drain and Korle } \\
\text { Lagoon to solve the } \\
\text { perennial flooding in } \\
\text { Accra in order to save } \\
\text { lives and property }\end{array}$ & 10 million & - & $\begin{array}{l}\text { Arthur- } \\
\text { Mensah } \\
(2017)\end{array}$ \\
\hline $\begin{array}{l}\text { Relief and } \\
\text { Repair } \\
\text { Project }\end{array}$ & 2015 & $\begin{array}{l}\text { A relief and repair } \\
\text { efforts following } \\
\text { flooding with an } \\
\text { associated fire killed } \\
\text { about } 200 \text { people in the } \\
\text { commercial hub of } \\
\text { Accra }\end{array}$ & 12 million & $\begin{array}{l}\text { Government } \\
\text { of Ghana }\end{array}$ & $\begin{array}{l}\text { The } \\
\text { Economist } \\
\text { Group (June } \\
\text { 23rd 2016) }\end{array}$ \\
\hline $\begin{array}{l}\text { Accra } \\
\text { Sanitation, } \\
\text { Sewer, } \\
\text { Stormwater } \\
\text { and Drainage } \\
\text { Alleviation } \\
\text { Project }\end{array}$ & 2013 & $\begin{array}{l}\text { Improving the } \\
\text { drainage system in } \\
\text { Accra to control the } \\
\text { perennial flooding and } \\
\text { sanitation challenges } \\
\text { in the city }\end{array}$ & 595 million & $\begin{array}{l}\text { Loan } \\
\text { facilities } \\
\text { with the } \\
\text { EXIM Bank } \\
\text { of the USA } \\
\text { and Standard } \\
\text { Chartered } \\
\text { Bank }\end{array}$ & BBC (2015) \\
\hline $\begin{array}{l}\text { Dredging the } \\
\text { Odaw River }\end{array}$ & 2011 & $\begin{array}{l}\text { Improving the } \\
\text { drainage system of the } \\
\text { Odaw }\end{array}$ & 1.2 million & - & $\begin{array}{l}\text { The Daily } \\
\text { Graphic } \\
(2012)\end{array}$ \\
\hline $\begin{array}{l}\text { Dredging } \\
\text { Committee } \\
\text { for Chemu } \\
\text { Lagoon }\end{array}$ & 2010 & $\begin{array}{l}\text { Improving the } \\
\text { drainage system of the } \\
\text { Chemu }\end{array}$ & 2 million & - & $\begin{array}{l}\text { Business } \\
\text { Ghana } \\
(2010)\end{array}$ \\
\hline
\end{tabular}


and reactive (i.e., to avoid similar flood-related damages and loss experienced during previous floods). Centralized adaptation measures to flooding in Accra encompass AMA or government sponsored projects carried out to dredge principal drainage channels; the commonly reported were the Odaw River and Korle-Lagoon. The decentralized adaptation measures involved dredging minor drainage channels sponsored through community fundraising. Finally, gradual adaptation measures to flooding are evidenced by the individual's decision to change from building more permanent and expensive homes on or near principal waterways to avert high economic losses when the structures are damaged due to flooding or government demolition. Further, as mentioned previously, a few of the respondents have adopted gradual adaptation strategy by enrolling in life and property insurance schemes against accidents and life-threatening disasters. Conversely, AMA- or governmentled demolition of structures before onset of rains to reduce risk of flooding and associated damages and causalities is mainly an abrupt adaptation measure.

\section{Limits and Barriers to Adaptation to Flooding}

A notable limitation to individual and community funded dredging reported was noncooporation and noncompliance among some community members. It was reported that, often, people are unwilling to contribute financially to enable the community leaders hire the services of private dredging companies. A major reason cited for noncontribution was "to some people this whole dredging activities is the responsibility of the local assembly and the government" [An assembly man at Alajo]. Therefore, there was no need for the individual to take over what the government must do for the community or city.

Further, despite community and/or government massive investments in dredging and related projects, the impact of these projects, in general, seemed to be short-lived because as illustrated in Fig. 2, (i) the open drain system results in faster accumulation of silt and solid waste, (ii) the dredged materials are often left on the banks of the drainage, which leads re-siltation of the waterways after few rain events, (iii) lack of enforcement of town plans and building permits, and (iv) there is also a societal habitat of massive littering and disposing of domestic and industrial waste into drains, leading to rapid refilling of dredged drainage channels. According to Mensah and Ahadzie (2020), improper urban disposal of waste can heighten flood events. Findings here suggest a need for AMA to invest in the construction of more robust drainage systems to build flood resilience in Accra. Interviews with planning and private urban planning consultants emphasized the urgent need for more sustainable development infrastructure in Accra and in other flood-prone cities, for example, by switching from open drain to close drainage system to abate using drainage channels as dumping sites. 


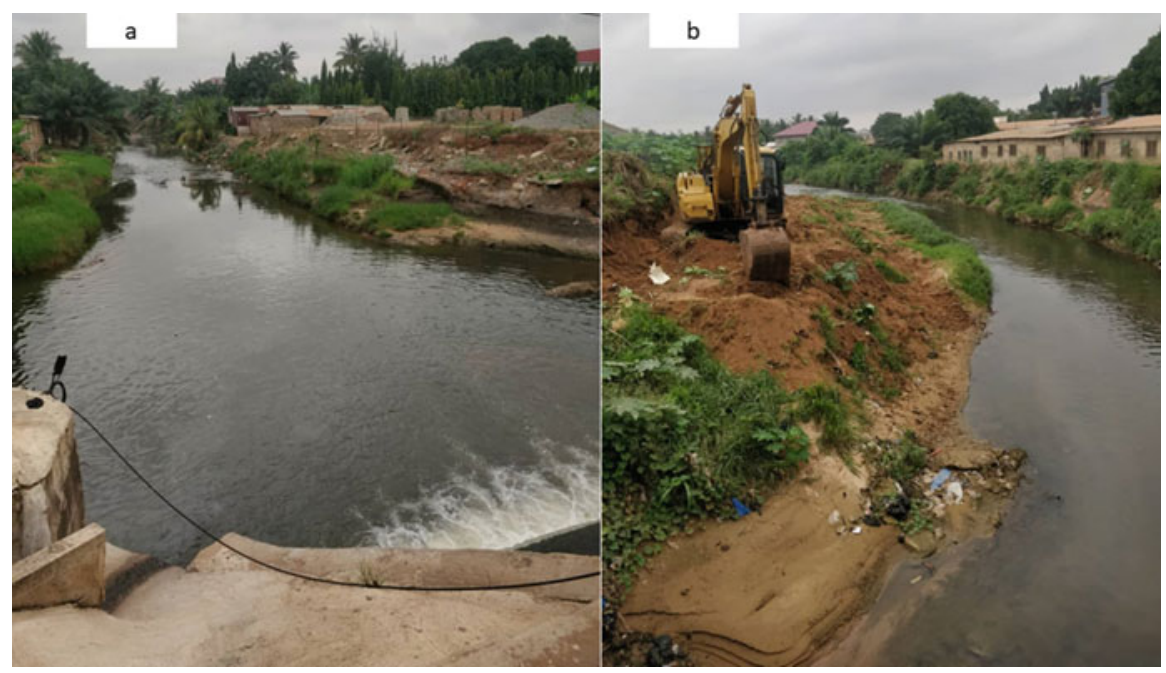

Fig. 2 (a) Location of residential buildings near open drainage and (b) excavation and disposition of dredged materials to drainage banks, which lead to rapid re-siltation and increases flood risk in Accra

\section{Conclusions and Perspectives}

Findings illustrate the perennial flooding in Accra that continue to cause massive property damage and occasional loss of lives. The main cause of flooding in the city was found to be the siltation of the Korle-Lagoon and the Odaw River and its tributaries, the construction of houses on waterways, and flood plains due mainly to lax enforcement of building permits. The very nature of development, that is, the building of open drains coupled with poor sanitation attitude among residences, results in the blockage of drains in the city that accounts for most of the flood episodes. This is supported by the fact that the Accra plains where the city of Accra is located is actually the driest part of Ghana with average annual precipitation totally $800 \mathrm{~mm}$ yet Accra is the most flooded city in the country.

Findings showed that flooding in Accra has enormous adverse impacts on household income, property, and employment. The main adaptation measures at the level of the individual, community, and government include building less permanent and inexpensive structures to reduce economic cost of flood-induced damages, dredging of drains ahead of rainfall and demolishing of buildings on or near waterways. Nevertheless, the adaptation measures, in general, were reported to be ineffective to make the city resilient to flooding. A major contribution of the study is showing that flood forecasting by GMet plays a crucial role in mitigating the devastating impact of flooding on household socio-economic livelihoods in Accra. Findings also points to the need for city authorities to implement robust measures to make Accra more resilient to flood in the era of climate change. It is suggested that, 
in the short-term, effort of making sure that dredged materials are not deposited on the banks of the drainage channel to prevent rapid re-siltation is needed. The dredged material could be put into good use in construction and landfill. However, because of high level of pollution, more studies on how safely to dispose of or potentially use the dredged material should be done. Long-term adaptation such as robust engineering solutions, for example, covering open drains and building of retention ponds that will reduce surface runoff in the city, should be considered. There are a few green spaces like the Achimota forest and large undeveloped land near the city that can be created as retention ponds to help solve the perennial flooding problem in Accra. A potential limitation of the study is that the conclusions presented in the present work are based on a sample size of 320 from 10 flood-prone neighborhoods. It is recommended that future similar studies are conducted in other flood-prone neighborhoods in Accra and elsewhere in Ghana to expand the present work to improve the generalization of the findings for spatial planning and interventions to alleviate impact of flooding on urban livelihoods.

\section{References}

Aboagye D (2012) Living with familiar hazards: flood experiences and human vulnerability in Accra, Ghana. J Urban Res. https://doi.org/10.4000/articulo.2110

Ahmed F, Moors E, Khan MSA, Warner J, Terwisscha van Scheltinga C (2018) Tipping points in adaptation to urban flooding under climate change and urban growth: the case of the Dhaka megacity. Land Use Policy 79:496-506. https://doi.org/10.1016/j.landusepol.2018.05.051

Alcamo J, Olesen JE (2012) Life in Europe under climate change. Wiley-Blackwell, Chichester

Amoako C (2012) Emerging issues in urban flooding in African cities-the case of Accra, Ghana. Paper presented at the 35th AFSAAP annual conference proceedings 2012

Appeaning Addo K, Appeaning Addo I (2016) Coastal erosion management in Accra: combining local knowledge and empirical research. Jàmbá: J Disaster Risk Stud 8(1). https://doi.org/10. 4102/jamba.v8i1.274

Arthur-Mensah G (2017) Government should pay contractors for dredging Odaw-MP. Ghana News Agency. Available at: https://www.modernghana.com/news/780971/government-should-paycontractors-for-dredging.html. Accessed June 10, 2020

Asumadu-Sarkodie S, Owusu PA, Rufangura P (2015) Impact analysis of flood in Accra, Ghana. Adv Appl Sci Res 6(9):53-78

BBC (2015) Ghana petrol station inferno kills about 150 in Accra. BBC. http://www.bbc.com/news/ world-africa-33003673. Accessed 5 June 2015

Business Ghana (2010) Ghana inaugurates dredging committee for Chemu Lagoon, April 1, 2010

CNN World (2001) Ghana floods leave thousands homeless. CNN.com, June 28, 2001

Daily Graphic (2015) Flood disaster profile of Ghana since 1968. Daily Graphic, June 5, 2015

Darko KA (2020) One dead as military, NADMO move to rescue Accra flood victims. 9 June 2020

Dewan TH (2015) Societal impacts and vulnerability to floods in Bangladesh and Nepal. Weather Clim Extremes 7:36-42. https://doi.org/10.1016/j.wace.2014.11.001

Güneralp B, Güneralp I, Liu Y (2015) Changing global patterns of urban exposure to flood and drought hazards. Glob Environ Chang 31:217-225. https://doi.org/10.1016/j.gloenvcha.2015. 01.002

IPCC (2000) IPCC special report on emissions scenarios. In: Nebojsa Nakicenovic RS (ed) Special report on emissions scenarios. Cambridge University Press, Cambridge, UK, p 612

IPCC (2007) Climate change 2007: synthesis report. Contribution of Working Groups I, II and III to the fourth assessment report of the Intergovernmental Panel on Climate Change IPCC, Geneva 
IPCC (2018) Summary for policymakers. In: Masson-Delmotte V, Zhai P, Pörtner H-O, Roberts D, Skea J, Shukla PR, Pirani A, Moufouma-Okia W, Péan C, Pidcock R, Connors S, Matthews JBR, Chen Y, Zhou X, Gomis MI, Lonnoy E, Maycock T, Tignor M, Waterfield T (eds) Global warming of $1.5^{\circ} \mathrm{C}$. An IPCC special report on the impacts of global warming of $1.5^{\circ} \mathrm{C}$ above pre-industrial levels and related global greenhouse gas emission pathways, in the context of strengthening the global response to the threat of climate change, sustainable development, and efforts to eradicate poverty. World Meteorological Organization, Geneva, $32 \mathrm{pp}$

Jahanbazi M, Egger U (2014) Application and comparison of two different dual drainage models to assess urban flooding. Urban Water J 11(7):584-595. https://doi.org/10.1080/1573062X.2013. 871041

Jamshidi O, Asadi A, Kalantari K, Azadi H, Scheffran J (2019) Vulnerability to climate change of smallholder farmers in the Hamadan province, Iran. Clim Risk Manag 23:146-159. https://doi. org/10.1016/j.crm.2018.06.002

Kim Y, Eisenberg DA, Bondank EN, Chester MV, Mascaro G, Underwood BS (2017) Fail-safe and safe-to-fail adaptation: decision-making for urban flooding under climate change. Clim Chang 145(3):397-412. https://doi.org/10.1007/s10584-017-2090-1

Kwarteng EM (2007) Aftermath of floods. Daily Graphic, June, 23, pp 18

Maskey S, Trambauer P (2015) Hydrological modeling for drought assessment. In: Paron P, Di Baldassarre G, Shroder JF (eds) Hydro-meteorological hazards, risks, and disasters, Hazards and disasters series. Elsevier, Amsterdam, pp 263-282

Mensah H, Ahadzie DK (2020) Causes, impacts and coping strategies of floods in Ghana: a systematic review. SN Appl Sci 2(5):792. https://doi.org/10.1007/s42452-020-2548-z

Ministry of Works and Housing (2019) Greater Accra Resilient and Integrated Development Project. The Environmental Impact Assessment [EIA] Study for the Dredging in The Odaw Basin, GARID

Møller-Jensen L, Kofie RY, Yankson PWK (2005) Large-area urban growth observations - a hierarchical kernel approach based on image texture. Geografisk Tidsskrift-Danish J Geogr 105(2):39-47. https://doi.org/10.1080/00167223.2005.10649538

Okyere CY, Yacouba Y, Gilgenbach D (2012) The problem of annual occurrence of floods in Accra: an integration of hydrological, economic and political perspectives. ZEF University of Bonn, Bonn

Owusu Boadi K, Kuitunen M (2002) Urban Waste Pollution in the Korle Lagoon, Accra, Ghana. Environmentalist 22(4):301-309. https://doi.org/10.1023/A:1020706728569

Owusu K, Teye KJ (2015) Supplementing urban water supply with rainwater harvesting in Accra, Ghana. Int J Water Resour Dev 31(4):630-639. https://doi.org/10.1080/07900627.2014.927752

Owusu K, Yankson PWK, Asiedu AB, Tutu-Benefor T (2019) Climate change impacts on two coastal metropolitan areas in Ghana. In: Climate change in Ghana. The human dimension. Afram Publication (Ghana) Limited, Accra

Rain D, Engstrom R, Ludlow C, Antos S (2011) Accra Ghana: a city vulnerable to flooding and drought-induced migration. UN-Habitat, Nairobi

The Daily Graphic (2012) The dead Odaw River - polluted with plastics, garbage \& human excreta. GhanaWeb. Mar 13, 2012. http://www.ghanaweb.com/GhanaHomePage/. The Daily Graphic

The Economist Group (June 23rd 2016) One year on, Ghana floods again. Available: http://country. eiu.com/article.aspx?articleid $=1994343383 \&$ Country $=$ Ghana\&topic $=$ Economy_1. Accessed June 15,2020

The Weekend Globe (2013) Danger: pollution of Odaw increases. http://www.ghanaweb.com/ GhanaHomePage/NewsArchive/Danger-Pollution-of-Odaw-increases-286634. Accessed 25 June 2016

The World Bank (2019) Greater Accra Resilient and Integrated Development Project (P164330)

UN-Habitat (2009) Ghana: Accra urban profile. UN-Habitat, Regional and technical Co-operation Division, Nairobi

UN-Habitat (2011) Housing profile. Nairobi 
United Nations Office for the Coordination of Humanitarian Affairs (OCHA) (2002) Ghana - floods OCHA, Accra

Viglione A, Rogger M (2015) Flood processes and hazards. In: Paron P, Di Baldassarre G, Shroder JF (eds) Hydro-meteorological hazards, risks, and disasters. Hazards and disasters series. Elsevier, Amsterdam, pp 3-33

Willems P, Arnbjerg-Nielsen K, Olsson J, Nguyen VTV (2012) Climate change impact assessment on urban rainfall extremes and urban drainage: methods and shortcomings. Atmos Res 103:106118. https://doi.org/10.1016/j.atmosres.2011.04.003

www.macrotrends.net (2020) Accra, Ghana metro area population 1950-2020. https://www. macrotrends.net/cities/21107/accra/population\#: :text=Chart\%20and\%20table $\% 20$ of $\% 20$ pop ulation, $\mathrm{a} \% 201.58 \% 25 \% 20$ increase $\% 20$ from $\% 202019$

Open Access This chapter is licensed under the terms of the Creative Commons Attribution 4.0 International License (http://creativecommons.org/licenses/by/4.0/), which permits use, sharing, adaptation, distribution and reproduction in any medium or format, as long as you give appropriate credit to the original author(s) and the source, provide a link to the Creative Commons license and indicate if changes were made.

The images or other third party material in this chapter are included in the chapter's Creative Commons license, unless indicated otherwise in a credit line to the material. If material is not included in the chapter's Creative Commons license and your intended use is not permitted by statutory regulation or exceeds the permitted use, you will need to obtain permission directly from the copyright holder.

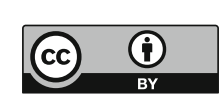

